\title{
Special issue in law and economics
}

\author{
Nuno Garoupa
}

Received: 17 June 2009 / Accepted: 17 June 2009 / Published online: 1 July 2009

(C) Springer-Verlag 2009

When Nobel laureate Ronald Coase wrote his famous piece (Coase 1960) he may not have realized or guessed that he was giving birth to a new exciting field, Law and Economics. By the time Judge Posner wrote his seminal book (Posner 1972), Law and Economics was an established field in Economics. In the last 35 years, Law and Economics has become a central methodology in legal scholarship. Economists have moved to law schools and shaped so many areas of legal scholarship that now it is difficult to understand contracts, torts, property and corporate law without being familiar with economic concepts such as efficiency, transaction costs, principal-agent model, moral hazard and adverse selection, among others. No matter how legal scholarship evolves in the next 50 years, the contributions of economists will be certainly enduring and path-breaking. The next generations of lawyers will be trained in the economic jargon, and the judges will write decisions citing economic analysis. Economics will be inside the courts. Economics will be part of the discourse in legal policy making.

Obviously all of this is true in the USA. But not in Europe. Law and economics is still very much a marginal field in economic departments and almost ignored by the faculties of law, with some exceptions here and there. There are structural reasons for the lack of success of economists in European legal scholarship that cannot be easily addressed (Garoupa and Ulen 2008). One of the standard arguments put forward by European legal scholars is that economists use American models and American law to develop their arguments. Although this is far from true, this special issue is yet another move into showing how economics can inform legal policy discussions in Europe.

\footnotetext{
N. Garoupa $(\bowtie)$

University of Illinois College of Law, 504 E Pennsylvania Ave., Champaign, IL 61820, USA

e-mail: ngaroupa@illinois.edu
} 
The papers collected in this issue apply standard law and economic models to recent legal reforms across Europe. The different style of each paper shows how these models can be used in variable ways: from the more technical and stylized model that points out to a particular trade-off that should have been considered by legal policy makers to a more informal economic analysis that provides a powerful and generalist critique. These different styles embody the richness of Law and Economics methodology. They also show how economists and lawyers can write together, using economic language, to address fundamental legal problems.

I have selected applications to recent legal changes in Portugal, Spain, France, Italy and Greece. These are EU countries with traditional and longstanding problems with their legal systems, inefficient courts and ineffective laws. Their legal systems are simply unprepared to face the challenges posed by globalization and the technological advancements of our modern society. The governments of these countries have reacted late and slowly to the shortcomings of their legal systems. Economic analysis has not penetrated their legal thinking and, consequently, the current reform efforts have largely not been inspired by a serious economic discussion (except when it comes to considering budgetary costs). In that respect, this collection of papers provides useful examples to legal policymakers across Southern Europe and France.

In the first paper, Antonio Nicita and Matteo Rizzoli look at Italian reforms of labor law, in particular the regulation of strikes. They develop a formal model to assess the incentives provided by "virtual strikes," both in terms of the goals of the workers and the losses borne by the employers. A social welfare analysis is applied to discuss the merits of this alternative to classical strikes. The model is used to inform current policy changes in Italy.

Bruno Deffains, Roberto Galbiati and Sebastien Rouillon also use a formal model to address current reforms in France in the area of criminal law. They assess the introduction of minimum mandatory penalties. They show that such a policy might increase acquittals, and therefore dilute criminal deterrence, thus backfiring on the governmental policy of law and order. This is a good example of a policy change that might actually not deliver the results politicians expect because the structure of incentives has been neglected.

In the third paper, I present a short extension of the economic model of litigation to show that the introduction of payments upfront when legal fees are allocated according to the English rule can actually congest courts. I argue that the reform of legal fees designed by the Portuguese legal policymakers is naïve in that respect. It provides a second example of a policy change that could undermine the results announced by politicians.

The fourth paper is authored by Fernando Gómez-Pomar, Anna Ginès i Fabrellas, and Ignacio Marín García. They look at the problems posed by litigation where the State is the defendant. Looking at the Spanish experience, they discuss the incentives to bring a suit and settle out-of-court when there is a clear asymmetry of bargaining positions. Their paper provides a useful framework to discuss the reforms of administrative courts, and the extent 
to which administrative procedure should be used to correct potential biases favorable to the State.

The final paper is by Aristides Hatzis. In a more informal way, the author discusses the recent changes in regulation of surrogate motherhood in Greece. He identifies a lack of economic analysis and addresses the detrimental incentives created by the new law. He concludes that the prevalence of paternalism in legal policy analysis fails to produce sensible policies in the area of family law.

I welcome this opportunity to thank the contributors to this special issue of the Portuguese Economic Journal for their superb work. Each paper was delivered under very tight deadlines which were met by all contributors. The authors and I are grateful to the seven anonymous referees for the quality and speed of their suggestions. A final word to thank Paulo Brito for the idea and the opportunity to have a special issue published by the Portuguese Economic Journal on the subject of law and economics.

\section{References}

Coase R (1960) The problem of the social cost. J Law Econ 3:1-44

Garoupa N, Ulen TS (2008) The market for legal innovation: law and economics in Europe and the United States. Ala Law Rev 59(5):1555-1633

Posner R (1972) Economic analysis of the law. Little Brown, Boston 